South African Journal of Geomatics, Vol. 3, No. 2, August 2014

\title{
A comparison of Normalised Difference Snow Index (NDSI) and Normalised Difference Principal Component Snow Index (NDPCSI) techniques in distinguishing snow from related land cover types
}

\author{
Phila Sibandze ${ }^{1}$, Paidamwoyo Mhangara ${ }^{1}$, John Odindi $^{2}$, Mahlatse Kganyago ${ }^{1}$ \\ ${ }^{1}$ South African National Space Agency, Earth Observation, Pretoria, psibandze@sansa.org.za \\ ${ }^{2}$ School of Agricultural, Earth and Environmental Sciences, University of KwaZulu-Natal, Pietermaritzburg
}

DOI: http://dx.doi.org/10.4314/sajg.v3i2.6

\begin{abstract}
Snow is a common global meteorological phenomenon known to be a critical component of the hydrological cycle and an environmental hazard. In South Africa, snow is commonly limited to the country's higher grounds and is considered one of the most destructive natural hazards. As a result, mapping of snow cover is an important process in catchment management and hazard mitigation. However, generating snow maps using survey techniques is often expensive, tedious and time consuming. Within the South African context, field surveys are therefore not ideal for the often highly dynamic snow covers. As an alternative, thematic cover-types based on remotely sensed data-sets are becoming popular. In this study we hypothesise that the reduced dimensionality using Principal Components Analysis (PCA) in concert Normalized Difference Snow Index (NDSI) is valuable for improving the accuracy of snow cover maps. Using the recently launched 11 spectral band Landsat 8 dataset, we propose a new technique that combines the principal component imager generated using PCA with commonly used NDSI, referred to as Normalised Difference Principal Component Snow Index (NDPCSI) to improve snow mapping accuracy. Results show that both NDPCSI and NDSI with high classification accuracies of $84.9 \%$ and $76.8 \%$ respectively, were effective in mapping snow. Results from the study also indicate that NDSI was sensitive to water bodies found on lower grounds within the study area while the PCA was able to de-correlate snow from water bodies and shadows. Although the NDSI and NDPCSI produced comparable results, the NDPCSI was capable of mapping snow from other related land covers with better accuracy. The superiority of the NDPCSI can particularly be attributed to the ability of principal component analysis to de-correlate snow from water bodies and shadows. The accuracy of both techniques was evaluated using a higher spatial resolution Landsat 8 panchromatic band and Moderate Resolution Imaging Spectroradiometer (MODIS) data acquired on the same day. The findings suggest that NDPCSI is a viable alternative in mapping snow especially in heterogeneous landscape that includes water bodies.
\end{abstract}

\section{Introduction}

Snow is a common global meteorological phenomenon. On some of the earth's higher grounds, snow is known to be a valuable source of fresh water and therefore regarded as an important component of the hydrological cycle (Brown 2000; Yang et al., 2003; Zhou and Li 2003; Tong and Velicogna 2010). According to Bonan (2002), snow plays a significant role in influencing heat regimes and local, regional and even global radiation balance. Snow is also known to strongly influence regional soil characteristics, plant composition and plants community structure (Darmody et al., 2004; Löffler 2005). At local levels, snow cover is known to affect several soil parameters 
such as permeability, temperature, moisture, microbial activity and carbon sequestration (Monson et al., 2006; Isard et al., 2007) According to Lu et al., (2005), snow's distinct high surface reflectance and low thermal conductivity are believed to influence biological, chemical and geological processes. A number of studies (Chinn 2008; Kargel et al., 2005 among others) note that snow is a sensitive indicator to climate change.

In South Africa, snow is mainly experienced during winter months (June to August) and is common in the Western Cape mountains, western parts of the Northern Cape Province, interior high grounds of the Eastern Cape and the Drakensburg mountains in KwaZulu-Natal. Whereas the prevalence of snow in South Africa is not as high as the northern hemisphere's mid-latitudes and Polar Regions, the effects of annual snow is well documented. Like in other parts of the world, in South Africa, snow causes substantial ground transport disruptions, particularly on the country's high ground mountain passes, agricultural damage, overload on utilities like electricity and solar power output among others (Cheshire 1997; Andrews and Pearce 2012). Miller (1998) suggests that snow is a valuable physical process that promotes soil water infiltration that re-invigorates grasslands and other natural vegetation. In this regard, mapping snow is critical for sustainable utilisation of catchments, water points as well as planning and mitigation of associated disasters.

Traditionally, field surveys have been used to generate snow maps (Brown and Braaten 1998). However, generating snow maps using survey techniques is often expensive, tedious and time consuming (Kavzoglu and Colkesen 2009). Field surveys are therefore not ideal for the often quick melting snow covers ( $\mathrm{Lu}$ et al., 2005). Therefore, thematic cover-types based on remotely sensed data-sets are becoming popular (Foody, 2002; Gillanders et al., 2008). Remotely sensed data-sets are particularly well suited for measurement of snow cover due to their uniquely high incident radiation, which contrasts with most natural and artificial surface types (Stroeve et al., 2005). The suitability of remotely sensed datasets in snow cover mapping is further facilitated by repetitive temporal coverage, wide swath width, improved classification algorithms and acquisition of data from remote and inaccessible sites (Foody 2002).

To date, a number of techniques have been exploited by scientists to reliably map snow at various scales. Köning et al., (2001), Foppa et al., (2007) and Lu et al., (2005) provide a detailed overview of some the common remote sensing datasets and methods used in snow mapping. One of the most successful image based snow mapping techniques is the Normalized Difference Snow Index (NDSI) proposed Hall et al. (2001). This technique exploits the ratio between snow's high reflectance and strong absorption in the visible and short-wave infrared sections of the electromagnetic spectrum respectively (Hall et al., 2001). Like most ratios, Salomonson and Appel (2004) notes that one of the major advantages of NDSI is its resilience to atmospheric effects and influences caused by viewing geometry. In this regard use of NDSI has been widely adopted by the remote sensing community (see; Tong and Velicogna 2010; Andreassen et al., 2008; Aniya et al., 1996; Sidjak and Wheate, 1999; Corripio 2004 and Lu et al., 2005 among others).

As aforementioned, accurate mapping of snow cover is valuable for planning, management and the mitigation of adverse bio-physical and social process. Whereas the use of NDSI has been widely used in mapping snow, the reliability of such maps is often compromised by its reflectance similarity with other cover types like water, shiny rock surfaces and even vegetation covers. According to Hall et al., (2002), such features are characterised by low reflectance due to their high absorbance ability and low NDSI denominator. Under such circumstances, even a small increase in in the infra-red band may ultimately increase the NDSI and therefore a misclassification of the alternative land-cover's type pixel as snow (Hall et al., 2002). Köning and Sturm (1998) note that there is still a need for techniques that can be used to improve the classification accuracy of snow cover maps. One of the techniques with great potential is the use of imagery principal components, 
also known as Principal Component Analysis (PCA). The PCA is a multivariate statistical technique used in remote sensing to reduce the number of spectral components to fewer principal components with most of the variance contained in the original multispectral images (Singh, 1989). Typically, remotely sensed image dataset are characterised by multiple bands. However, some of the bands within the dataset are often highly correlated and therefore redundant for land-use-landcover mapping (Muchoney and Haack 1994; Munyati 2004). In PCA, spectral bands are combined into a new set of less correlated eigen images (Jackson 1983). In this study we hypothesise that the reduced dimensionality using PCA in concert NDSI is valuable for improving the accuracy of snow cover maps. Whereas there is a huge body of literature on the use of PCA in land-use-land-cover mapping, there is paucity of literature on the integration of PCA in NDSI for snow cover mapping. Using the recently launched 11 spectral band Landsat 8 dataset, we propose a new technique that combines the imagery principal components generated using PCA with commonly used NDSI, referred to as Normalised Difference Principal Component Snow Index (NDPCSI) to improve snow mapping accuracy.

\section{Study Area}

The Koue Bokkeveld mountain range is located north of Ceres town in the Western Cape Province of South Africa (Figure 1). The Koue Bokkeveld has an elevated escarpment which extends to about $1,600 \mathrm{~m}$ above sea level. At this altitude, it is one of the coldest places in the Western Cape and experiences snow fall every winter season. The mountain range forms part of the Koue Bokkeveld mountain catchment draining into the Olifants and Doring River networks. The area is regarded as an important natural ecosystem and a critical water source that is used to irrigate approximately $50 \%$ of the agricultural fields within the catchment (IWRM Report 2011). This area was selected due to the significance of snow to the catchments hydrological system and other aforementioned reasons.

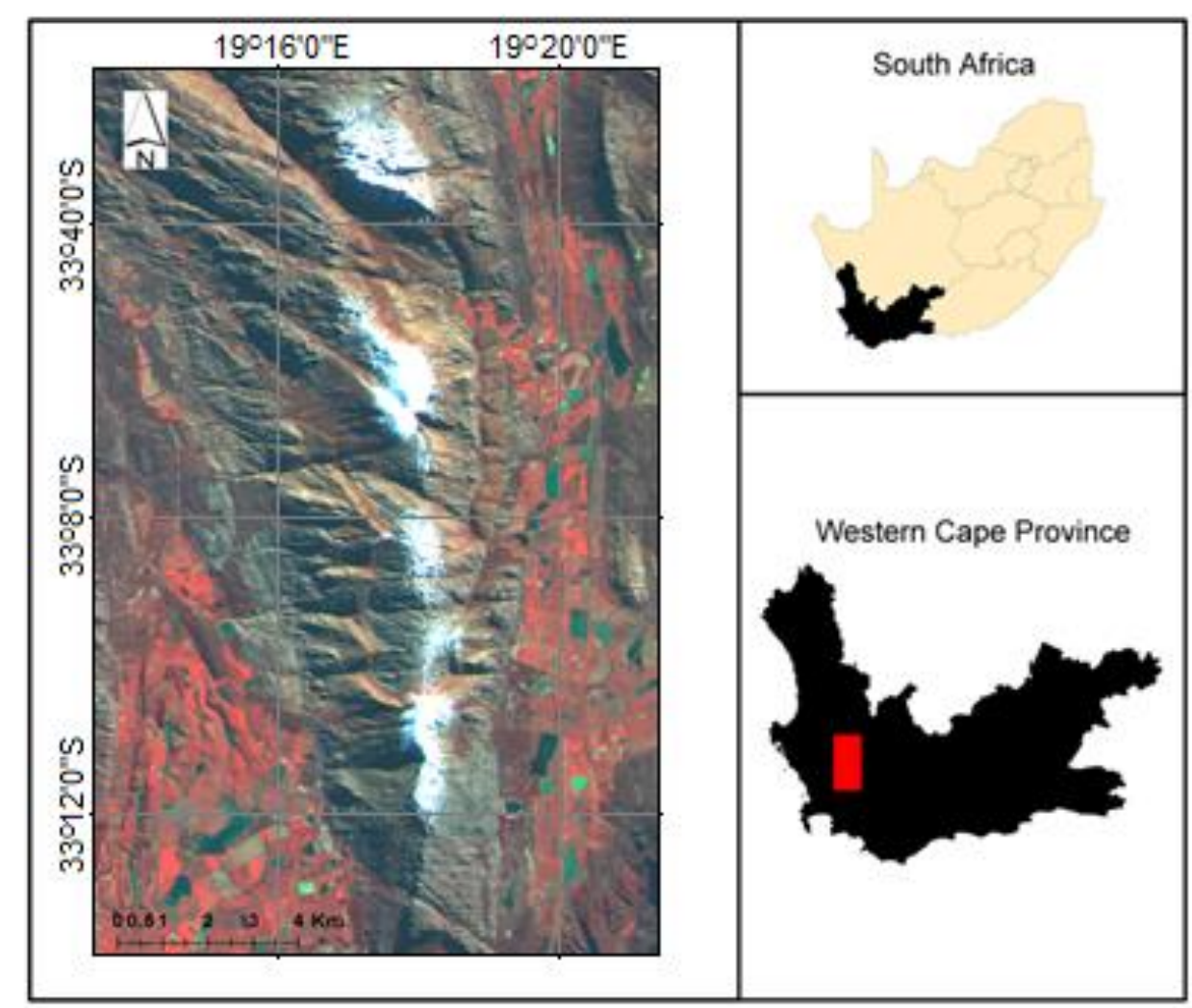

Figure 1. Location of the study area. 


\section{Data and Methods}

The area's Landsat 8 level 1A dataset was acquired on the $9^{\text {th }}$ of June 2013 from the South African National Space Agency (SANSA). This image was captured on the earliest cloud free day after a snow fall. The dataset is characterised by 11 spectral bands operating in the visible, nearinfrared, shortwave infrared and thermal infrared spectral regions. The imagery is further characterised by $30 \mathrm{~m}$ spatial resolution bands from the visible and shortwave infrared, $100 \mathrm{~m}$ for thermal infrared and $15 \mathrm{~m}$ spatial resolution for the, panchromatic band. For this study we only used the $30 \mathrm{~m}$ spatial resolutions bands for deriving the snow indices and the $15 \mathrm{~m}$ panchromatic band for validation. A detailed description of the characteristics of Landsat 8 imagery is available on the United States Geological Survey (USGS) Landsat Missions website at http://landsat.usgs.gov.

The level 1A Landsat image acquired for this study consisted of quantized and calibrated scaled digital numbers representing multispectral image (USGS 2013). The digital numbers of the images were converted to surface reflectance to obtain the Top of Atmosphere (TOA) reflectance as suggested by Smith et al. (2013). To exploit the high reflectance of snow in the visible and the shortwave infrared wavelength regions, and to accentuate the presence of snow in the study area, we employed the NDSI. This technique was preferred over other snow identification methods such as the Relative Spectral Mixture Analysis (RMSA) and the Relative Multiple Endmember Spectral Mixture Analysis (RMESMA). Unlike NDSI, Shreve et al (2009) noted that RMSA and RMESMA yield inferior snow classification accuracy. In this study, NDSI was computed by dividing the difference in reflectance observed in the Landsat 8 green band $(0.53-0.59 \mu \mathrm{m})$ and the shortwave infrared band $(1.57-1.65 \mu \mathrm{m})$ with the sum of the two bands as per equation 1 .

$$
N D S I=\frac{\text { Green }_{0.53}-S W I R_{1.65}}{\text { Green }_{0.568}+S W I R_{1.65}}
$$

As recommended by Hall et al., (1995), Kulkarni et al., (2006) and Xiao et al., (2002), we used a NDSI threshold of greater than 0.4 to highlight the presence of snow. As suggested by Kulkarni et al., (2006) and Xiao et al., (2002) a near-infrared reflectance value greater than 0.11 was used to mask out water pixels so as to improve NDSI classification accuracy.

To accentuate tonal variations and to reduce dimensionality and correlated principal components, we applied the PCA technique to all the Landsat 8's visible, near-infrared and short wave infrared bands. This procedure generated eight spectrally independent principal components. Each principal component was then independently analysed to detect snow. A Normalised Difference Principal Component Snow Index (NDPCSI) was then computed to accentuate the presence of snow using principal component 1 and 2 as illustrated in the equation 2.

$$
N D P C S I=\frac{P C_{\text {brightest }}-P C_{\text {darkest }}}{P C_{\text {brightest }}+P C_{\text {darkest }}}
$$

A flow chart of procedures followed in the study is detailed in Figure 2. 


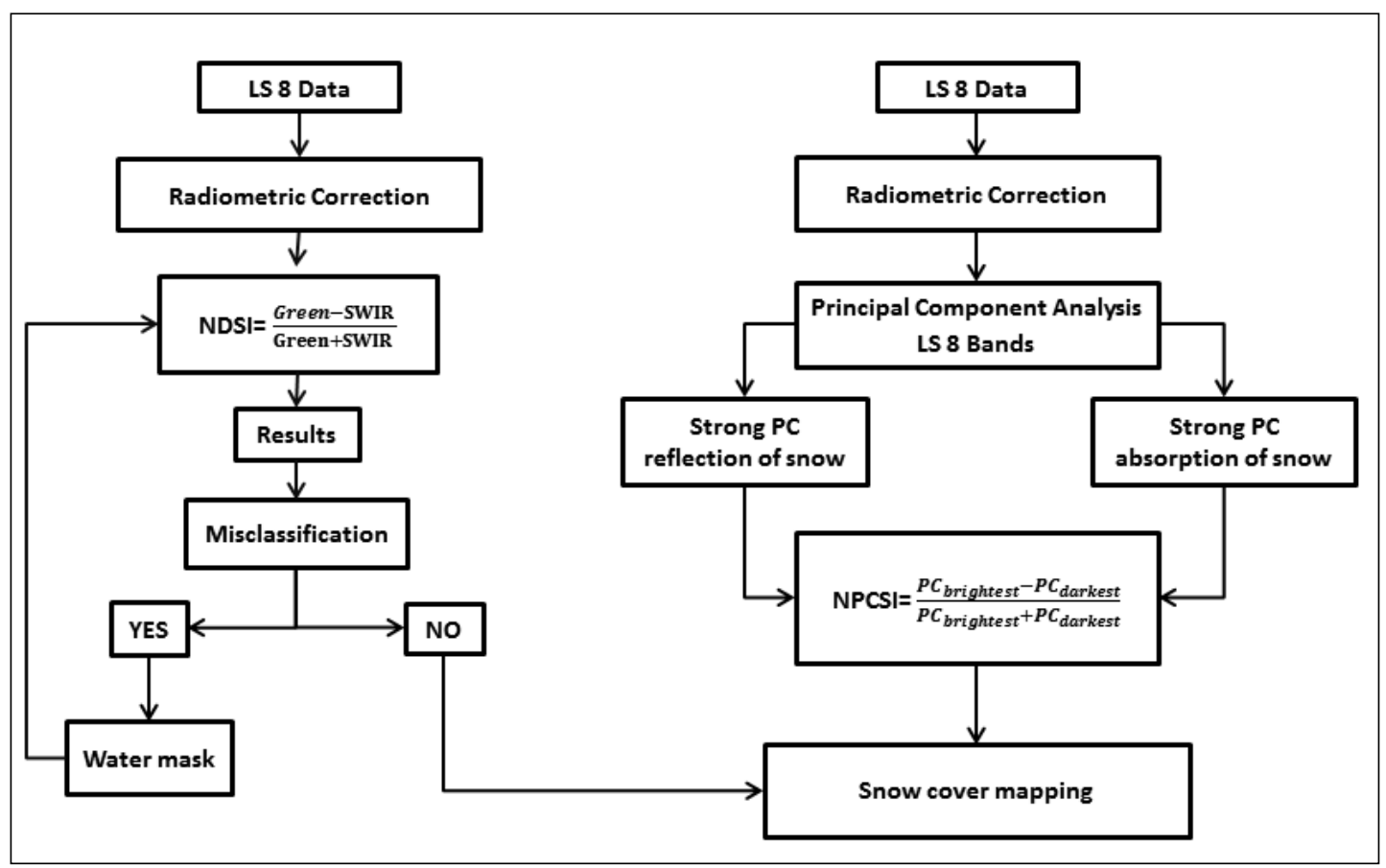

Figure 2. Processing flow diagram of the study.

\section{Validation and evaluation}

Given the challenge of obtaining same day snow ground reference data for validation in inaccessible mountain terrains, MODIS data was used as reference dataset for accuracy assessment. The MODIS sensor consists of 36 spectral bands between the electromagnetic spectrum of 0.4$14 \mu \mathrm{m}$ with a spatial resolution of 250, 500 and $1000 \mathrm{~m}$ at nadir (Hall et al., 1995). With such a wide spectral range, MODIS is ideal for mapping snow cover using the visible, infrared and shortwave infrared regions (Hall et al., 1995). Detailed characteristics of MODIS can be found in Huang et al., (2011). Ideally the validation process should be done using higher spatial resolution data. However, it was impractical to get same day reference image and to perform field verification due to the limited time frame as snow melted before a much higher resolution sensor overpass. Therefore to complement the MODIS data for accuracy assessment, a 15 metre higher resolution Landsat 8 panchromatic band was therefore used in evaluating the classification accuracy. Stroeve et al., (2005) and Lydolph (1985) noted that snow reflects more than $80 \%$ of the incident radiation. In consistency with these observations, in this study, it was relatively easy to discern snow covers from the course resolution MODIS validation imagery. Consequently, the accuracy of snow covers based on NDSI and NDPCSI were validated using MODIS and the Landsat 8 panchromatic band classified as "snow" and "no snow".

\section{Results and discussions}

In consistency with findings in literature (see; Hall et al., 1995, 2001, 2002; Kulkarni et al., 2006 and Xiao et al., 2002 among others), at a threshold greater than 0.4, the NDSI analysis was successful in distinguishing snow from other land cover types. However, results in this study also indicated that NDSI was sensitive to water bodies found on lower grounds within the study area (Figure 3a). This finding is consistent with Hall et al., (2002) who note such spectral confusion as the major weakness of NDSI in mapping snow in areas with reflective water bodies (see Figure 4). As aforementioned, to improve the snow cover classification accuracy, it was therefore necessary to mask out the visible water bodies from the NDSI image (Figure 3b). The resultant image showed a significant improvement in delineating areas of spectral confusion between snow and water bodies (Figure 3c). Figure 3d shows NDSI's snow covers using a snow/no snow Boolean mask. 

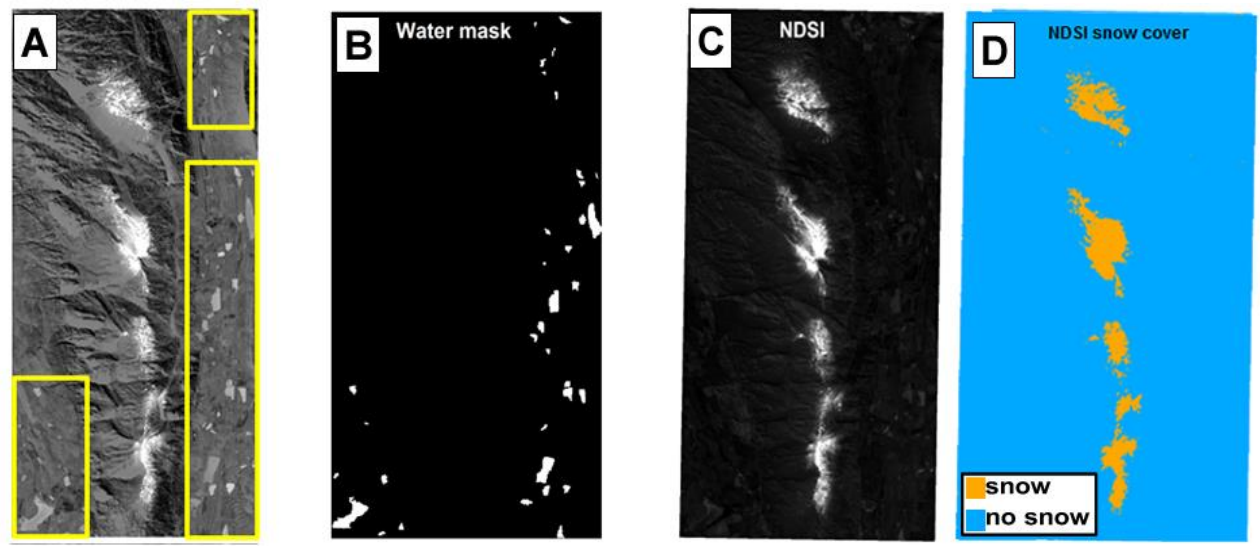

Figure 3. NDSI misclassification of snow with water bodies - rectangles (A), water bodies mask (B), NDSI with water masked out (C) and Binary image of areas with and without snow (D).

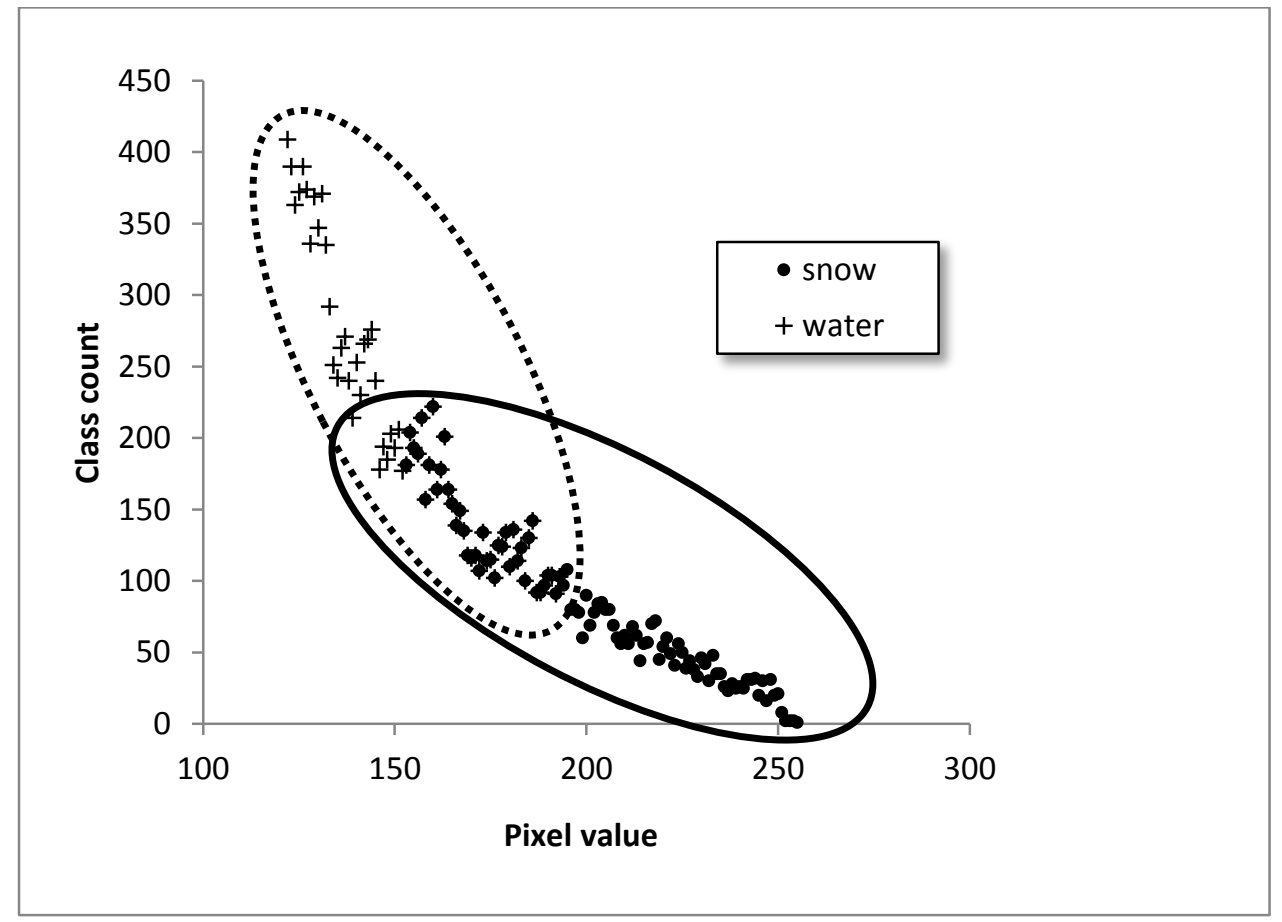

Figure 4: Scatter plot showing snow and water overlap using NDSI.

The 8 PCAs showed different amount of information. The greatest amount of information was contained in principal components (PC) 1 and 2. Generally, there was a higher variation in surface cover types in PC1 than in the rest of the 8 PCs. As shown in Figure 4-PC1, the high reflectance and high absorption for snow and water bodies respectively made them easily distinguishable. However, whereas PC2 had more information than the rest of lower order PCs, it was difficult to distinguish snow from most of the other surfaces. In PC2, the absorption of both snow and water reduced the contrast between the two surfaces (Figure 5- PC 1 and PC 2). The PC 1 and 2 were therefore chosen for calculation of the NDPCSI as they showed high reflectance and absorption for snow covers respectively. The eigenvalues showed that the two PCs had over $88 \%$ of meaningful data (Table 1). The contrast between the two PCs and the therefore the validity of choice for mapping snow was further corroborated using a correlation scatterplot and were found to be spectrally unrelated (Figure 6). 

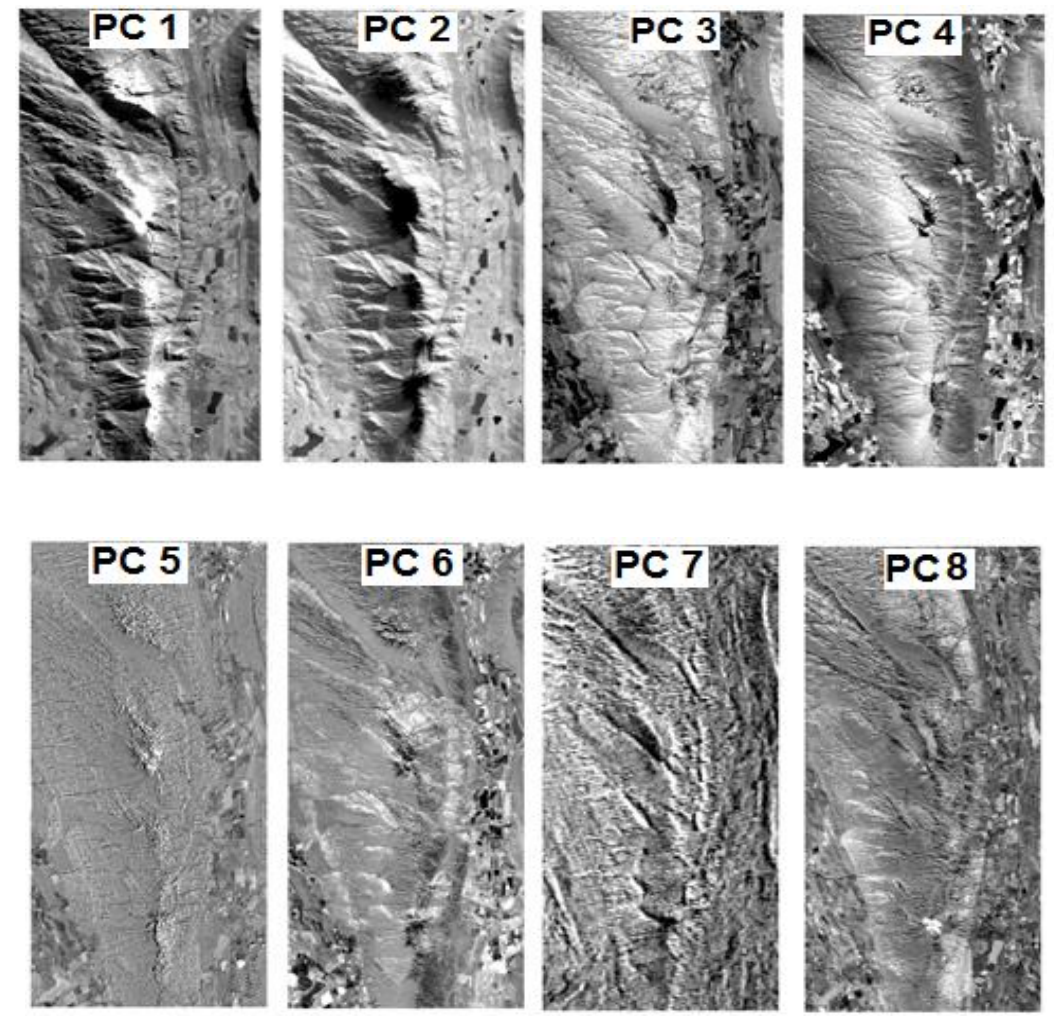

Figure 5. Principal components 1 to 8 - PC 1 and PC 2 show snow reflectance and absorption respectively.

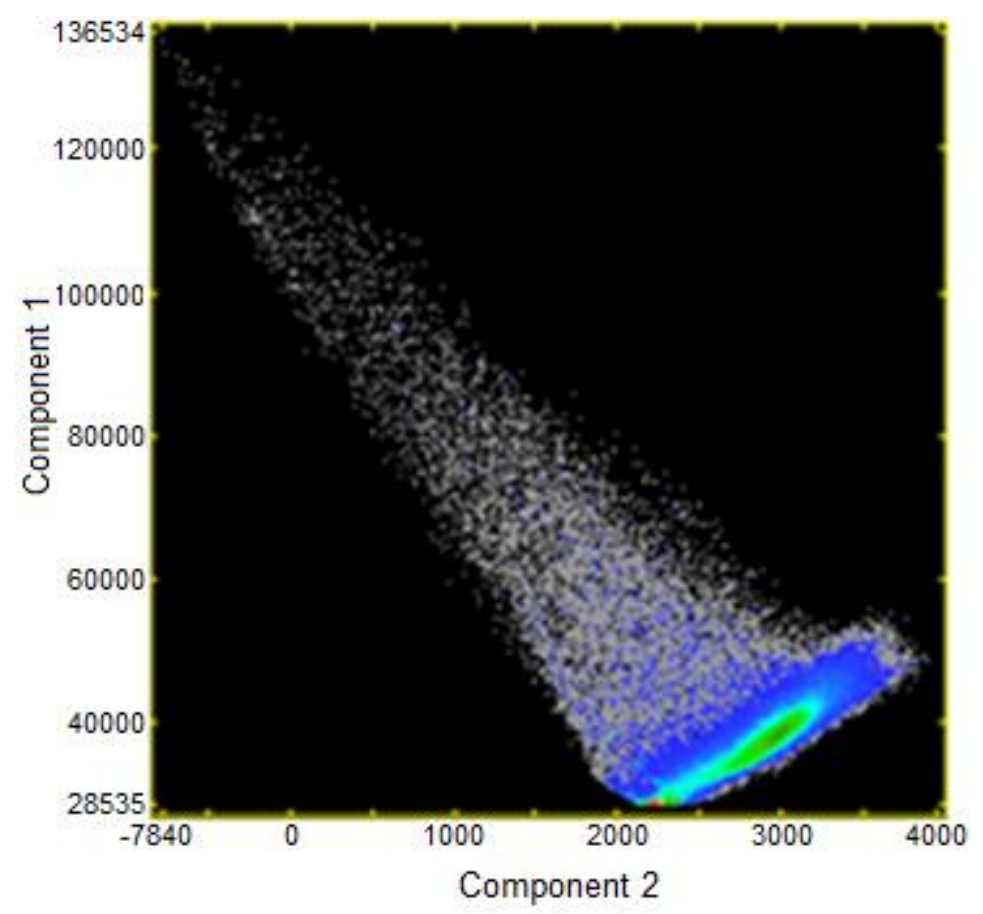

Figure 6. Scatterplot between principal component 1 and 2.

Less than $12 \%$ of the information was contained in the six higher order PCs (Table 1). These PCs indicated high variances of noise and were therefore not considered for calculation of NDPCSI. 
Table 1: Eigenvalues representing information from the 8 principal components.

\begin{tabular}{|c|c|c|c|}
\hline PC & Eigenvalues & Percentages & Cumulative Percentage \\
\hline 1 & 11833725.950 & 65.364 & 65.364 \\
\hline 2 & 4248676.094 & 23.468 & 88.832 \\
\hline 3 & 1357968.744 & 7.501 & 96.333 \\
\hline 4 & 477560.191 & 2.638 & 98.971 \\
\hline 5 & 127015.446 & 0.702 & 99.672 \\
\hline 6 & 33036.812 & 0.183 & 99.855 \\
\hline 7 & 23197.801 & 0.128 & 99.983 \\
\hline 8 & 3136.417 & 0.017 & 100.000 \\
\hline
\end{tabular}

The resulting NDPCSI indicated that there was a substantial difference between snow cover and other land cover types in the imagery such as water bodies, agricultural fields, roads, and build up areas. Unlike the NDSI, NDPCSI clearly differentiated snow from water bodies without the need of a water mask. Ultimately, an extract of thick snow covering an area of $7 \mathrm{~km}^{2}$ was delineated from the rest of the classes (Figure 7).
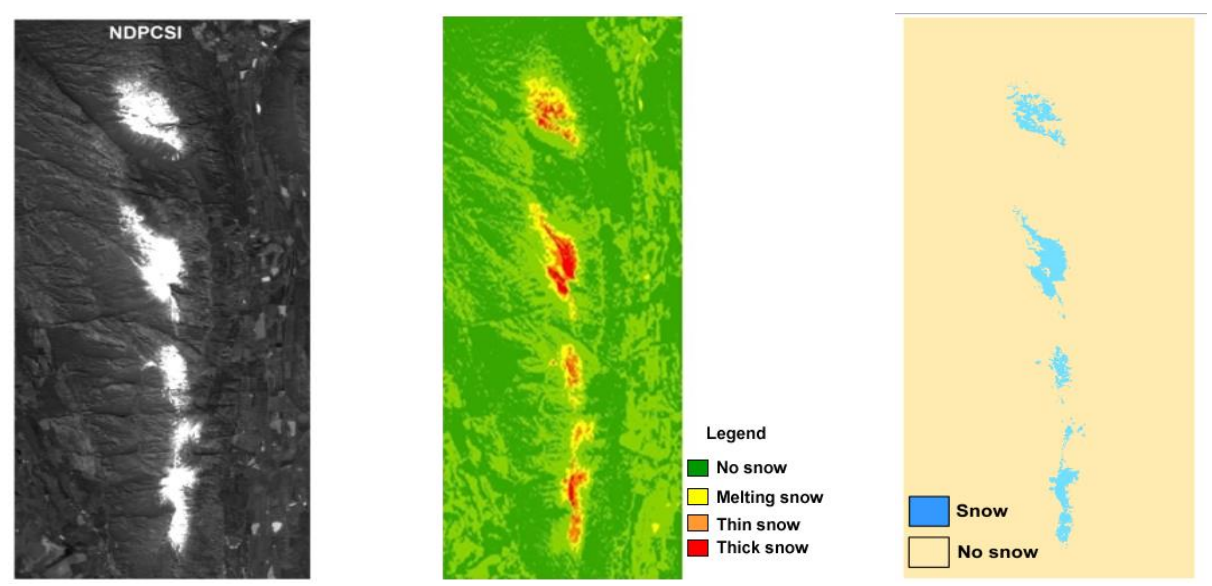

Figure 7. Snow cover mapped from NDPCSI.

As aforementioned, to assess the accuracy of the mapped snow, the validation using NDSI and NDPCSI was done using MODIS data and the Landsat 8 panchromatic band. Figure 8 shows same day acquisition of snow cover in the study area from both MODIS and Landsat 8 spectral and panchromatic imagery. Although MODIS had a courser resolution, areas covered by snow were visible. 

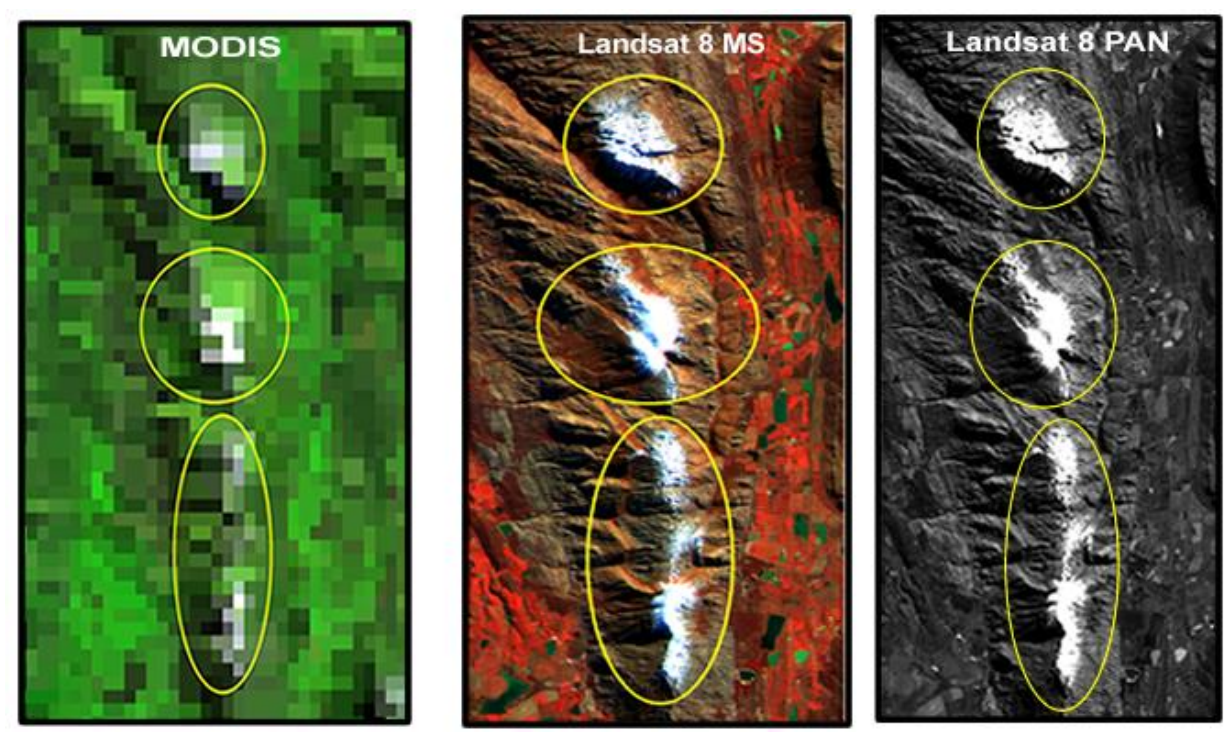

Figure 8. MODIS and Landsat 8 multispectral and panchromatic imagery showing snow cover.

Table 2, table 3, table 4 and table 5 present the results of the confusion matrix obtained from the validating NDSI and NDPCSI methods. Validation of these methods was performed using MODIS data which produced overall accuracies of $76.8 \%$ and $84.9 \%$ for NDSI and NDPCSI respectively. On the other hand, the panchromatic band produced significantly higher overall accuracy for both methods with $93.7 \%$ for NDSI and $94.9 \%$ for NDPCSI. These results indicate how significant these two sets of imagery were in testing NDSI and NDPCSI methods. The results obtained in this study indicate that the accuracy of the mapped snow using NDSI is comparable to NDPCSI. However, whereas the NDPCSI performed better than the NDSI, the computation for NDSI is simple and can be automated. Therefore, the choice of the two methods will be determined by the volume of the images to be processed and the level of classification accuracy required.

Table 2. Confusion error matrix of the NDSI using MODIS.

\begin{tabular}{ccccccc}
\multicolumn{7}{c}{ (Ground Truth Pixels) } \\
& no snow 1 & no snow 2 & no snow 3 & snow & Total \\
\hline Unclassified & 0 & 0 & 0 & 0 & 0 \\
no snow & 20 & 3 & 0 & 0 & 23 \\
no snow & 0 & 17 & 12 & 0 & 17 \\
no snow & 0 & 0 & 0 & 0 & 12 \\
no snow & 0 & 0 & 0 & 0 & 0 \\
snow & 0 & 0 & 0 & 10 & 10 \\
\hline Total & 20 & 20 & 12 & 10 & 62 \\
\hline
\end{tabular}

Overall accuracy: $76.81 \%$ 
Table 3. Confusion error matrix of the NDPCSI using MODIS.

\begin{tabular}{cccccccc}
\multicolumn{7}{c}{ (Ground Truth Pixels) } \\
& no snow 1 & no snow 2 & no snow 3 & snow 1 & snow 2 & Total \\
\hline Unclassified & 0 & 0 & 0 & 0 & 0 & 0 \\
no snow 1 & 0 & 0 & 0 & 0 & 1 & 1 \\
no snow 2 & 28 & 76 & 0 & 0 & 0 & 104 \\
no snow 3 & 0 & 23 & 36 & 0 & 0 & 59 \\
snow 1 & 0 & 0 & 0 & 408 & 11 & 419 \\
snow 2 & 0 & 0 & 0 & 0 & 0 & 0 \\
\hline Total & 28 & 99 & 36 & 408 & 12 & 583 \\
\hline \multicolumn{7}{c}{ Overall accuracy: 84.9\% }
\end{tabular}

Table 4. Confusion error matrix of the NDSI using Landsat 8 panchromatic band.

\begin{tabular}{ccccc} 
& \multicolumn{3}{c}{ Ground Truth Pixels } & Total \\
& unclassified & snow & no snow & \\
\hline unclassified & & 0 & 0 & 0 \\
snow & 0 & 98 & 10373 & 10468 \\
no snow & 0 & 4713 & 223247 & $\mathbf{2 2 4 9 6 0}$ \\
\hline total & 0 & 4811 & $\mathbf{2 3 3 6 1 7}$ & $\mathbf{2 3 8 4 2 8}$ \\
\hline \multicolumn{5}{c}{ Overall accuracy: $93.67 \%$}
\end{tabular}

Table 5. Confusion error matrix of the NDPCSISI using Landsat 8 panchromatic band.

\begin{tabular}{ccccc} 
& \multicolumn{3}{c}{ Ground Truth Pixels } & Total \\
& unclassified & snow & no snow & \\
\hline unclassified & 0 & 0 & 0 & 0 \\
snow & 0 & 0 & 7434 & 7434 \\
no snow & 0 & 4811 & 226186 & 230994 \\
\hline total & 0 & 4811 & 233617 & 238428 \\
\hline \multicolumn{4}{c}{ Overall accuracy: $94.86 \%$}
\end{tabular}

\section{Conclusions}

This study demonstrated that snow cover can be mapped using Landsat 8 imagery using NDSI and NDPCSI techniques. Although the NDSI and NDPCSI produced comparable results, the NDPCSI produced higher classification accuracy. The superiority of the NDPCSI can be attributed to the ability of principal component analysis to de-correlate snow from water bodies and shadows. The NDSI results confirmed the threshold of 0.4 widely used in literature as ideal for mapping snow. Although with a relatively lower accuracy, a major advantage of NDSI over NDPCSI is the possibility for automation. However, the use of NDPCSI offer great potential to achieve higher accuracy snow maps if the PCs with the greatest de-correlation can be automated. Furthermore, use of NDPCSI eliminates the need to masking features with similar spectral characteristics as snow. This study demonstrates that NDPCSI can be used successfully to map snow and is an alternative to the commonly used NDSI. 


\section{References}

Andreassen, LM, Paul, F, Kääb, A, \& Hausberg, JE 2008, Landsat-derived glacier inventory for Jotunheimen, Norway, and deduced glacier changes since the 1930s, The Cryosphere, vol. 2, pp. 131-145.

Andrews, R \& Pearce, J 2012, Prediction of energy effects on photovoltaic systems due to snowfall events in, 38th IEEE Photovoltaic Specialists Conference, pp. 003386-003391.

Aniya, M, Sato, H, Naruse, R, Skvarca, P \& Casassa, G 1996, The use of satellite and airborne imagery to inventory outlet glaciers of the Southern Patagonian Icefield, South America. Photogrammetric Engineering and Remote Sensing, vol. 62, pp. 1361-1369.

Bonan, G 2002, Ecological Climatology, Concepts and Applications, Cambridge University Press, New York.

Brown, RD 2000, Northern Hemisphere snow cover variability and change, 1915-1997, Journal of Climate, vol. 13, pp. 2339-2355.

Brown, BD, \& Braaten, RO 1998, Spatial and temporal variability of Canadian monthly snow depths, 19461995, Atmospheric Ocean, vol. 36, no.1, pp. 37-54.

Cheshire, L 1997, Have snow shovel, will travel. National Snow and Ice Data Centre, viewed 28 January2014,〈http://www.southafrica.info/news/snow70812.htm\#.UvklPLTGcxA\#ixzz2swrQccLH>.

Chinn, H, Salinger, J, Fitzharris, B, \& Willsman, A 2008, Glaciers and climate. Bulletin of the Federal Mountain Clubs of New Zealand, vol. 171, pp. 1-15.

Corripio, JG 2004, Snow surface albedo estimation using terrestrial photography, International Journal of Remote Sensing, vol. 25, no. 24, pp. 5705-5729.

Darmody, RG, Thorn, CE, Schlyter, P, Dixon, JC 2004, Relationships of vegetation distribution to soil properties in Kärkevagge, Swedish Lapland, Arctic, Antarctic and Alpine Research, vol. 36, pp. 21-32.

Foody, GM 2002, Status of land cover classification accuracy assessment, Remote Sensing of Environment, vol. 80, pp. 185-201.

Foppa, N, Stoffel, A \& Meister, R 2007, Synergy of in situ and space borne observation for snow depth mapping in the Swiss Alps, International Journal of Applied Earth Observation and Geoinformation, vol. 9, pp. 294-310.

Gillanders, SN, Coops, NC, Wulder, MA, Gergel, SE, Nelson, T 2008, Multitemporal remote sensing of landscape dynamics and pattern change: describing natural and anthropogenic trends, Progress in Physical Geography,vol. 32, pp. 503-528.

Hall, DK, Foster, JL, Chien, JL. \& Riggs, GA 1995, Determination of actual snow-covered area using Landsat TM and digital elevation model data in Glacier National Park,Montana, Polar Record, vol. 31, no.177, pp.191-198.

Hall, DK, Riggs, GA. \& Solomonson, VV 1995, Development of methods for mapping global snow cover using moderate resolution imaging spectroradiometer data, Remote Sensing of Environment, vol. 54, pp.127-140. 
Hall, DK, Riggs, GA, Salomonson, VV, Barton JS, Casey, KL, Chien, NE, DiGirolamo, AG, Klein, H, Powell W, \& Tait, AB 2001, Algorithm theoretical basis document (ATBD) for the MODIS snow and sea ice-mapping algorithms, viewed 3 October 2013, <http://www.modissnowice.gsfc.nasa.gov/atbd01.html.>

Hall, DK, GA, Riggs, VV, Salomonson, N, DiGirolamo \& KJ, Bayr 2002, MODIS snow-cover products, Remote Sensing of the Environment, vol. 83, no.1-2, pp. 181-194.

Huang, X, Liang, T, Zhang, X \& Guo, Z 2011, Validation of MODIS snow cover products using Landsat and ground measurements during the 2001-2005 snow season over northern Xinjiang, China, International Journal of Remote Sensing, vol. 32no.1, pp. 133-152.

Isard, SA, Schaetzl, RJ, \& Andresen, JA 2007, Soils cool as climate warms in the great lakes region: 19512000, Annals of the Association of American Geography, vol. 97, pp. 467-476.

IWRM 2011, Western Cape IWRM Action Plan: Status Quo Report Final Draft 2011, viewed 1 October 2013, <http://www.westerncape.gov.za/other/2011/8/chapter_11_the_olifants_doorn_wma.pdf.>

Jackson, BB 1983, Multivariate Data Analysis: An Introduction Irwin, Richard Irwin, Homewood/ Illinois, USA.

Kavzoglu, T, Colkesen, I 2009, A kernel functions analysis for support vector machines for land cover classification, International Journal of Applied Earth Observation and Geoinformation, vol. 11, pp. 352359.

Kargel, J S, Abrams, M J, Bishop, M P, Bush, A, Hamiton, G, Jiskoot, H, K“a”ab, A, Kieffer, HH, Lee, EM, Paul, F, Rau, F, Raup, B, Shroder, J F, Soltesz, D, Stainforth, D, Stearns, L, \& Wessel, R 2005, Multispectral imaging contributions to global land ice measurements from space, Remote Sensing of the Environment, vol. 99, pp. 187-219.

Köning, M, Winther, JG, \& Isaksson, E 2001, Measuring snow and glacier ice properties from satellite, Reviews of Geophysics, vol. 39, no. 1, pp. 1-27.

Köning, M, \& Sturm, M 1998, Mapping snow distribution in the Alaskan Arctic using aerial photography and topographic relationships, Water Resources Research, vol. 34, no. 12, pp. 3471-3483.

Kulkarni, AV, Singh, SK, Mathur, P \& Mishra, VD 2006, Algorithm to monitor snow cover using AwiFs data of RESOURCESAT-1 for the Himalayan region, International Journal of Remote Sensing. vol. 27, no.12, pp. 2449-2457.

Löffler, J 2005, Snow cover dynamics, soil moisture variability and vegetation ecology in high mountain catchments of central Norway, Hydrological Processes, vol. 19, pp. 2385-2405.

Lu, S, Oki, K \& Omasa, K 2005, Mapping snow cover using AVHRR/NDVI 10-day composite data, Journal of Agricultural Meteorology, vol. 60, no. 6, pp. 1215-12-18.

Lydolph, E 1985, The Climate of the Earth, Rowman \& Littlefield, Maryland. Monson, RK, Burns, SP, Williams, MK, Delany, AC, Weintraub, M, Lipson, DA 2006, The contribution of beneath-snow soil respiration to total ecosystem respiration in a high-elevation, subalpine forest, Global Biogeochemical Cycles, 20, GB3030, doi: 10.1029/2005GB002684.

Miller, D. 1998, Nomads of the Tibetan Plateau Rangelands in Western China, Part One: Pastoral History. Rangelands, vol. 20, no. 6, pp. 24-29. 
Muchoney, DM \& Haack, BN 1994, Change detection for monitoring forest defoliation, Photogrammetric Engineering and Remote Sensing, vol. 60, pp. 1243-1251.

Munyati, C 2004, Use of Principal Component Analysis (PCA) of Remote Sensing Imaging in Wetland change detection on Kafue Flats, Zambia, Geocarto International, vol. 19, no. 3, pp. 1787-1806.

Shreve, CM, Okin, GS \& Painter, TH 2009, Indices for estimating fractional snow cover in the western Tibetan Plateau, Journal of Glaciology, vol. 55, 192, 2009, p.737-745

Sidjak, RW \& Wheate, RD 1999, Glacier mapping of the Illecillewaet Icefield, British Columbia, Canada, using Landsat TM and digital elevation data. International Journal of Remote Sensing, vol. 20, pp. 273-284.

Smith, R, Bonneau, L, Lee, X, Woo, L, Fein, F 2013, Yale Guide to Landsat 8 Image Processing. Viewed 6 September 2013, <http://www.yale.edu/ceo/Documentation/Landsat\%208\%20image\%20processing.pdf>

Salomonson, V \& Appel, I 2004, "Estimating fractional snow cover from MODIS using the normalized difference snow index," Remote Sensing of Environment, vol. 89, pp. 351-360.

Singh, A 1989, Digital change detection techniques using remotely-sensed data. International Journal of Remote Sensing, vol. 6, pp. 989-1003.

Stroeve, J, Box, E, Gao, F, Liang, S, Nolin, A \& Schaaf, C 2005, Accuracy assessment of the MODIS 16day albedo product for snow: comparisons with Greenland in situ measurements, Remote Sensing of Environment, vol. 94, pp. 46-60.

USGS, Using the USGS Landsat 8 product. viewed 13 July 2013, <https://landsat.usgs.gov/Landsat8_Using_Product.php.>

Tong, J \& Velicogna, I 2010, A Comparison of AMSR-E/Aqua Snow Products with in situ Observations and MODIS Snow Cover Products in the Mackenzie River Basin, Canada Remote Sensing, vol. 2, pp. 23132322.

Xiao, X, Moore, B, Qin, X, Shen, Z, Boles, S 2002, Large-scale observations of alpine snow and ice cover in Asia: Using multi-temporal VEGETATION sensor data, International Journal of Remote Sensing, vol. 23, no. 11, pp. 2213-2228.

Yang, D, Robinson, D, Zhao, Y, Estilow, T, Ye, B 2003, Streamflow response to seasonal snow cover extent changes in large Siberian watersheds, Journal of Geophysics Research, vol. 108, pp. 4578.

Zhou, X, \& Li, S 2003, Comparison between in situ and MODIS-derived spectral reflectances of snow and sea ice in the Amundsensea, Antarctica, International Journal of Remote Sensing, vol. 24, no. 24, pp. 5011-5032. 